\title{
"Messin' with the Furniture Man": Early Country Music, Regional Culture, and the Search for an Anthological Modernism
}

\author{
J. M. Mancini
}

Furniture! Thank God, I can sit and I can stand without the aid of a furniture warehouse. What man but a philosopher would not be ashamed to see his furniture packed in a cart and going up country exposed to the light of heaven and the eyes of men, a beggarly account of empty boxes?

\section{Henry David Thoreau, Walden}

In the 1920s a boom in commercial recording brought hundreds of farmers, miners, carpenters, and preachers from rural places like Burton's Fork, Kentucky, to the very epicenters of urban America to sing and to play banjos, fiddles, and guitars into machines. With the help of a rapidly integrating consumer economy that linked city and country through the twin virtual networks of media and market, these machines turned this music - which only a generation before had existed only as practice-into things. These things, in turn, circulated not only in those great conurbations and unincorporated spaces but between and within every kind of place in the middle. One musician who made this journey was a young coal miner named Dick Justice (1906-ca.1950s) of Logan County, West Virginia, who traveled to Chicago in May of 1929 to record for Brunswick Records. Like the career of his fellow miner Dock Boggs (18981971), who left Norton, Virginia, in 1927 to set down 12 tracks for the same label in New York, Justice's recording career there met an abrupt end. Unlike Boggs, who returned to the mines for a quarter century but was rediscovered in the 1960s by folk revivalist Mike 
Seeger and spent his golden years performing before galleries of earnest young seekers after authenticity, Justice's retirement was permanent. By the 1960s all that remained of him were the circulating things he had made. Indeed, even these things, other than his version of the Francis Child ballad "Henry Lee," which gained new life as the first track on the first volume of Harry Smith's epic Anthology of American Folk Music (1952), seemed destined to disappear forever with Justice. ${ }^{1}$

Perhaps because the transgressive, modern culture of the urban 1920 s is so interesting, relatively less attention has been paid to figures like Justice and the world he lived in than to the denizens of speakeasies and jazz clubs and their haunts. ${ }^{2}$ Indeed, it has been tempting for generations of observers like Smith to see the preDepression South as the last vestige of premodern authenticity: to see it, in Greil Marcus's words, as an inscrutably "Old, Weird America" where folks divided their electricity-free evenings between playing murder ballads on homemade banjos and sitting around waiting for the end times (5). Perhaps less romantic, but similarly problematic, is the scarring post-1929 memory world made by Walker Evans, John Steinbeck, and their cohort, which has made it hard to imagine poor, rural places like Justice's Logan County as ever having been anything but what they are, incontestably, in the documentary art of the Depression: isolated, hermetic, destitute, and blasted. ${ }^{3}$ Indeed, despite their apparent claims upon our sympathy, these images have reinforced later viewers' false sense of distance from the rural American cultures of the 1920s and of the distance between the city and the country in the 1920s itself. We do not, after all, call the 1920s the Country Age. ${ }^{4}$ And, particularly since the collapse of Steinbeck's Left—and the rise in its place of antiglobalization critics like Naomi Klein-have made us forget the trouble that capitalism brought to Americans, these images have also to our sense that the culture and people of the rural 1920s were not premodern but antimodern, and to our tendency to define them solely in the backlash against modernity inscribed in the second rise of the Ku Klux Klan and the creep of Scopes Trial-style fundamentalism. ${ }^{5}$

What this essay will argue is that early American country music, and the regional culture in which it was enmeshed, instead represents an important aspect both of American modernity and American modernism. First, the songs themselves-both as music and text-speak to the ascendance in the rural South of a hybrid, circulatory consumer culture that emerged directly alongside the more familiar Jazz Age modernity of "Mongrel Manhattan" and other urban centers (A. Douglas). Second, the collection and entextualization of early country songs by American musicologists Alan Lomax, Ruth Crawford Seeger, and Harry Smith in the inter- and post-war
[T]hese [documentary] images have also contributed to our sense that the culture and people of the rural 1920s were not premodern but antimodern, and to our tendency to define them solely in the backlash against modernity inscribed in the second rise of the Ku Klux Klan and the creep of Scopes Trial-style fundamentalism. 
period represents a distinct branch of American modernism, which I will call metadiscursive or anthological modernism. Analogous to other forms of primitivist modernism in Europe and the US, this movement was driven by the desire to stave off the disappearance of "traditional" culture threatened by radio, commercial recording, and the market. As such, the folk revivalists' development of technologies for the inscription and containment of authenticity constitutes a key moment within a longer modernist trajectory whose roots extend to the ethnological styles of nineteenth-century art and social science and which continues in both the world-music movement and the antiglobalization critique itself.

\section{Re Possession: Dick Justice's “Cocaine” and Rural Modernity}

Although its keynote placement in the Harry Smith Anthology has rendered "Henry Lee" Justice's most frequently heard work, this weird and ancient murder ballad was not entirely representative of his repertory as a whole. For, while Justice certainly learned some songs from older musicians who learned them from older musicians and so on and so on back to the beginnings of the ballad tradition, he learned others from less "traditional" sources such as phonograph records, vaudeville and minstrel shows, commercially published sheet music, and the radio. ${ }^{6}$ Like the music of his more famous Logan County neighbor Frank Hutchison, whose recordings of "Last Scene of the Titanic" and "Long Way to Tipperary" show the influence of mass media and of commercial song sheets even in the remotest parts of the US, Justice's repertory was marked by the market. ${ }^{7}$ This was far from unusual. As Bill C. Malone argues in Singing Cowboys and Musical Mountaineers, many of the songs recorded by the first generation of "commercial" country musicians were themselves the products of an already highly commercialized musical world-the world of the Tin Pan Alley songster, the "long-forgotten broadside ballad vendor, equestrian hornpipe dancer, puppet show fiddler, medicine show banjoist, showboat band, minstrel tenor, singing circus clown, ragtime pianist, or vaudeville vocalist" (67).

At the same time, "Henry Lee" is also atypical of Justice's repertory in that it comes directly from an English (or Scottish) ballad tradition that mixed freely with African (or African-American) and Irish (or Irish-American) sources in the region and was only sometimes found on its own. Thus, when Justice went to the big city to make a name for himself as a musician, he not only set down "Henry Lee" but a range of tracks including his version of an 1890s minstrel song known as "Furniture Man," which he considerably reworked into a song he called 
"Cocaine." As much as any of the music recorded in this period by urban performers, this brief output was defined by diversity, hybridity, and fluidity. In other words, it was not the product of a premodern (or antimodern) isolation that separated the rural South from "modern" places like New York but of an evolving modernity that (like the market that itself made the recording boom possible) joined the two regions in a common trajectory of consumerization, cultural dislocation and reformation, and the blurring of fixed social categories.

This is particularly true of "Cocaine," whose modernity can be seen on a number of levels. First, the song, like the modern urban culture of the 1920s described so vividly by Ann Douglas, was predicated on racial and regional mixing, belonging as it did to an interracial body of "Furniture Man" songs that had been performed since the 1890 s by both black and white musicians ranging from Victoria Spivey and Lonnie Johnson to Emmett Miller and his Georgia Crackers. ${ }^{8}$ Indeed, if Justice's "Cocaine" is a microcosm of hybrid modernity masquerading as Marcus's "old, weird America," this was also a defining feature of the Crackers' "Riley the Furniture Man," itself a product of the entertainment boom that brought Justice-and Spivey and Johnson-North. Like Justice and like legions of black and white Southerners both inside and outside of the music trade, ${ }^{9}$ Miller himself had made this trek after World War I, first leaving Macon, Georgia, for the minstrel circuit and then making his way to New York's big-time vaudeville stage and Okeh records in 1924. ${ }^{10}$

Thus, while "Riley the Furniture Man," with Miller's cracking Macon intonation and its sawing fiddle accompaniment-most likely Fiddlin' John Carson (Tosches, Country 100)—certainly has roots in the traditional musical practices of the white South, it is not an artifact of rural isolation. As a descendant of the "Furniture Man" family_and as a reworking, as well, of Luke Jordan's breakdown "Pick Poor Robin Clean"- the song by definition was a product of the interracial circulation that defined the minstrel market. More than that, Miller himself - the "Minstrel Man from Georgia"-was personally entrenched in the much more modern-seeming, much more familiar, hybrid world of Jazz Age New York. Indeed, it is no accident that the song's hillbilly fiddle and midword falsettos were driven by a surprisingly aggressive swinging bass line that challenges its classification as a simple country string number. It was no accident because "Emmett Miller's Georgia Crackers" was, in fact, not an unchanging band of bumpkins-even of the wandering sort immortalized in the Coen brothers' O Brother, Where Art Thou? (2000) - but merely the symbol for an unfixed cast of studio musicians that sometimes included old-time Southerners like Carson but more frequently incorporated future jazz immortals Gene Krupa, Tommy and Jimmy Dorsey, and Eddie Lang. ${ }^{11}$ 
If the interracial modernity of the circulating market defined "Furniture Man" as a musical artifact, this was also the defining feature of its texts. In Miller's version, then, the Furniture Man's agent is a "nigger driver" who is repeatedly ordered by Riley, a "white man who lives on $16^{\text {th }}$ Street," to "take down that rosewood bed!" but who, along with the Furniture Man and the market itself, victimizes white and black alike. As Miller sings,

Makes no difference to the white man

Just as white as crystal snow

If you don't pay Mr. Riley

He'll take your furniture sure

Riley's been here, got my furniture and gone.

What "Riley the Furniture Man" reveals, then, is not an unchanging or a doomed past but modernity in the making. Like the hybrid modernity of the interracial city, this modernity hardly promised racial equality. What it entailed, rather, was a mutually complicit engagement with the market that, like the hybridity it also promised, would eventually contribute to a corrosion of both older sources of isolation and older sources of inequality. While the world of the furniture man held out the very real possibility of continued victimization, it also promised that nothing - not even the racialized geography and economy of the segregated South-would remain fixed forever.

Despite the seemingly premodern cast of "Henry Lee," which as Justice's only track on the Harry Smith Anthology is his bestknown performance, this is also true of Justice's "Cocaine" and of his texts more generally. Virtually nothing is known of Justice's own life-it seems likely enough that he, like his more famous counterparts A. P. Carter and Hank Williams, had direct contact with black musicians, but anything beyond that is pure conjecture. Like the song itself, however, Justice's racially liminal narrator was clearly mixing it up. He sang,

I got a girl she works in white folks' yard She brings me meal I swear she brings me lard She brings me meal, honey, she brings me lard

She brings me everything, honey, that a girl can steal ("Cocaine")

Now, there are three ways to read the identity of the narrator of this stanza within the context of the song. The first two are obvious. Either the narrator is black, and Justice has adopted the persona of the black musicians whose music he emulated, or he is white, and he is sleeping with a black girl. What is more likely, in the words of 
Werner Sollors, is that Justice's narrator is "neither black nor white yet both"- -or, more precisely in this circumstance, that his race is shifting and situational, rather than fixed and permanent. ${ }^{12}$ For in the next stanza, Justice sings,

Lord a vaudeville circuit tried a came to town

They got to dancing with the nice and brown

They didn't know it's against the law

For the monkeys to stop at a five-cent store

Well just around the corner just a minute too late

Another one standing at the big back gate

I'm simply wild about my good cocaine

In other words, it would seem that Justice's narrator is black when he is with his girlfriend but white when the vaudeville circuit comes to town. Like the contemporary performance artist Nikki Lee, whose snapshots chronicle the shifting and situational nature of ostensibly authentic personal and cultural identities, Justice's song suggests that one of the lessons of consumer culture is that identity is not just about who one is, but with whom one is. ${ }^{13}$

This interpretation is corroborated by another aspect of "Cocaine's" narrative structure: the fact that Justice's narrator also appears to shift gender during the song. As we know, he's "got a girl." At the same time, however, the refrain of the song seems to identify him as a female prostitute. He sings,

I stood my corner, heh, hey

Here comes Sal with a note all told

Doctor says she couldn't smell no mo'

Lord brung the doctor ring the bell

The women in alleys

I'm simply wild about my good cocaine

While it is possible to see the narrator in this instance as a pimp or a pusher, his sympathy with Sal's condition (the narrator appears to have got the doctor), plus the song's general emphasis on the effects of the narrator's desperate quest for drugs (which implies that he is not the dealer), suggests that he himself (or rather, she herself) is standing her corner with the "women in alleys" to support her addiction. If in its hybridity "Cocaine" mirrors Lee's sympathetic and situational postmodernity, then, in its ambivalence the song's shifting narrative perspective is typical also of modernism itself.

So, then, what should we make of the vaudeville circuit's trip to town? Most obviously, Justice's narrator's tendency towards racial ambivalence and race mixing did not prevent him (or the narrator 
of "Riley") from also being racist. The vaudeville vignette seems to be related to black performer Lil McClintock's "Furniture Man":

Now Sally De Vose, everybody knows she's the swellest coon in town

She gave up all last Friday night, invite all the coons around the coons come in, shot full of gin they tried to raise a row there's nobody home but Sally De Vose, and these am the words she said

Take your time Mr. Brown, please take-a your time

all this furniture am mine

well a this piano, and everything

Mr. Cooper had it written down in my name

so take your time Mr. Brown, take-a your time

Nonetheless, McClintock's "coons" are by definition different from Justice's "monkeys." This is not where the story ends, however. For although Justice's narrator is racist, he also is a clear advocate of race mixing: the vaudevillians are foolish in this tale not for "dancing with the nice and brown," but for being dumb enough to think that this sort of thing was permissible in public in towns like his. In one sense, then, it is the city folk-the performers who have crept with the market into rural America-who are the rubes in this story, as they are unschooled in the harsh laws of Southern life: their downfall at the hands of the police comes because "they didn't know it's against the law / for the monkeys to stop in a five-cent store." More than that, however, Justice seems to be saying that it is the system itself that is foolish-why should they know such an absurd thing? Unlike performers from the city, who in New York and Chicago would certainly have understood that segregation was as much a fact of urban popular culture as race mixing, Justice's naïve narrator seems to be suggesting that in the "dream world" of mass consumption represented by the vaudeville circuit, the phonograph record, and the installment plan, commerce and pleasure alike are interracially accessible (R. Williams).

If in his embrace of race mixing Justice allied himself with one of the most powerful markers of urban modernity in 1920s, the same can be said of "Cocaine""s other major narrative theme: the visit of the dreaded Furniture Man. As scholars such as T. J. Jackson Lears and Roland Marchand have argued, a constituent element of American modernity between the 1890 s and the 1920 s was the rise of a new kind of consumer culture, fed by advertising, in which goods were promised to satisfy not only tangible, physical wants, but deeper social and psychological needs. ${ }^{14}$ In this new reality the acquisition of things-including addictive consumables like cocaine-filled 
a meaning vacuum left by migration, by the breakdown of religious, community, and kinship ties, and by the twin forces of urban growth and industrial dislocation. In other words, it is widely believed that people coped with modernity's harsh intangibles - fluidity, hybridity, alienation, de-skilling - through the consumption of its physical products.

As in other accounts of American modernity that, like Christine Stansell's American Moderns (2000), describe modernism as something that happened in New York, however, this narrative almost universally locates the rise of consumer culture, like modernity's other markers, within the urban sphere-in the seemingly urban technologies of advertising, public relations, and abstract art, in the urban locations of the department store, the dance hall, and the vice district, and in the urban environment's massive and greedy absorption of rural migrants. ${ }^{15}$ Figuring the consumer as 100 million Sister Carries, this literature-like the discourse of modernity itselftends to obscure a larger trend that marked the period: the integration of disparate rural areas, including isolated regions, into a nationally consolidated consumer economy. If modernity was made in the clubs of Harlem, the back rooms of the Tenderloin, and the cafés of the Lower East Side, it surely, too, was made in the hollers of Appalachia and the bayous of French Louisiana. Rural Americans did not just lash back at modernity but coped with it in many of the same ways as urbanites did: through the pursuit of pleasure, through hybridity, and through consumption.

A number of factors contributed to Southern modernity. First, as Edward Ayers argues in his fascinating and seminal Promise of the New South, rapid expansion in the Southern railroad system between the 1870s and the 1890s facilitated the ability of Southerners (like New Yorkers) to amass all of the things that modernity advertised, from bicycles to their own invention, Coca-Cola (9-11, 81, 101-02). And, as Bruce Bastin shows, the confluence of a number of factors within this context - the arrival of Montgomery Ward (1872) and Sears, Roebuck (1895); the institution of Rural Free Delivery (1896) and parcel post (1913); and the emergence of a period of agricultural prosperity in the first decades of the twentieth century-meant that by the 1920s the South was flooded with cheap guitars and other instruments, including many that ended up in the possession of those who had not had even the relative wealth to purchase them firsthand from Sears (14-18). Instruments were not the only musical goods to gain circulation in the rural South at this time. As Malone recounts, the father and brother of singer and song collector Jean Ritchie "walked eighty miles from the freight office in Jackson, Kentucky to bring home to their families in remote Perry County a brand-new talking machine" in the first decade of the twentieth century (Singing 
Cowboys 47-48). By the beginning of the Depression, these goods and the links between them fashioned a web of consumer capitalism that joined not only disparate Southern regions but virtually the entire US and shaped the culture of the pre-Depression South as surely as it did that of Jazz Age New York. ${ }^{16}$

Second, as Ronald D. Eller shows, industrialization in Appalachia between 1880 and 1930 sparked large-scale migration, as hundreds of thousands of people from rural areas left their homes for work in mines and in the mills of growing urban centers like Greenville and Spartanburg, South Carolina; Chattanooga and Bristol, Tennessee; and Rome, Georgia (125). And, as again Eller argues, this initial internal migration was mirrored in the later part of the period by a second wave of out-migration from the region, when "between 1923 and 1927, over 200,000 miners . . . left the American coal fields," mostly for destinations in the industrial Midwest (157). In the years between the Civil War and the 1920s, this emigration from the countryside, like emigration from abroad, instantiated new economic and cultural ties between those who left and those who stayed, which, like consumerization, would provide an important context for the popular culture that would develop in the period before the Great Depression.

The recording boom that gave rise to Justice's and Boggs's journeys typifies the complex process by which migration contributed to the emergence of a hybrid consumer culture in the pre-Depression South. On the one hand, before either musician dreamed of going North, paths to Georgia and Tennessee (and West Virginia and Virginia) had been already beaten by ambitious A \& R men from Northern-based companies like Victor and Okeh, whose trips to the South produced monumental events like the 1927 Bristol sessions, in which the Carter Family, Jimmie Rodgers, and a number of other early country stars first recorded their songs. At the same time, however, two things must be noted. First, many of the agents who actually arranged for the recordings of both country and blues to take place-including, for example, Burm Lawson of Union, South Carolina, who sent McClintock to Atlanta to record four tracks for Columbia Records, including "Furniture Man"-were themselves not only Southerners but Southerners who were already agents of consumerization. Lawson, after all, was not just Union's local agent for Columbia Records but the manager of Cooper's Furniture Store, which sold not only furniture but musical instruments to aspirant recording stars like McClintock ("Mr. Cooper had it written down in my name") and which provided him with practice space in anticipation of the journey to Atlanta. ${ }^{17}$ Indeed, as Charles K. Wolfe recounts, the "first" country record to be marshaled by legendary promoter Ralph Peer, Fiddlin' John Carson's "Little Old Cabin in the Lane" 
of 1923, came into being after Atlanta record distributor Polk C. Brockman - also a furniture man by trade—saw a silent film of Carson playing at a fiddlers' convention while on a business trip to New York (Classic Country 69-74). ${ }^{18}$

If furniture men like Brockman and Lawson were deeply entrenched in the circulatory world of consumer culture by the 1920s, so too were the musicians they recorded. Thus, before Brockman found himself sitting in a New York cinema getting ready to change the face of American popular music, Carson had already made one of the more typical sorts of journeys that would integrate the American economy, moving from Fannin County in North Georgia to work in the Atlanta mills. While in Atlanta, Carson began to create and to circulate in the burgeoning market for country music, playing and selling broadsheets around town (including an incendiary song that accused Governor John B. Slaton of colluding with New York banks to commute Leo Frank's death sentence, which suggests that market conspiracy theories spread as quickly as the market itself), traveling from town to town by car to widen his audience, and becoming the star of the South's first radio station, Atlanta's WSB, in 1922. While Carson and his promoters played up his rusticity in a gambit to sell his music, his activities, as Ayers notes, were essentially entrepreneurial (394-95). Like the makers of Atlanta's other "Real Thing," music makers surely recognized that nothing sells like the promise of authenticity (Malone, Singing Cowboys 75-76).

What also must be noted is that, even before this moment, a significant portion of the economic and musical groundwork for Carson's song, and for the thousands of songs that with it would comprise the recording boom, had already been laid. Thus, while it is possible to locate the emergence of a particular kind of consumer culture in the rural 1920s - as has been so elegantly argued for urban America in the same period-it is important, as Malone urges us, to remember that this was but one moment in a much longer trajectory of consumerization. "Little Old Cabin in the Lane," like "Furniture Man," was a well-known minstrel song and thus had circulated as a performance for decades before Carson recorded it. Indeed, it began its life as a thing: it was an 1871 creation of the prolific and influential songwriter William Shakespeare Hays, whose song sheets sold in the hundreds of thousands in the decades following the Civil War (Wolfe, Classic Country 67; Malone, Singing Cowboys 60-66). More generally, the nineteenth-century trade in sheet music itself helped pave the way for the commercial recording and the consumer boom of the 1920s, not only because it packaged songs as commodities but because it used one of the foundational technologies of consumer capitalism-the mail-order catalog-to build a far-flung audience not only for sheet music but for consumption itself. ${ }^{19}$ And 
indeed, this trade was but one reincarnation of a commercial trade in songs that extended back as far as modernity itself (and as globally forward as Amazon.com). Although folklorists like Child, and even anthologists like Smith, packaged American folk music as an ancient tradition and built their collections on variously formulated distinctions from market culture, murder ballads like "Henry Lee" had been made for many of the same reasons, and had taken on the same thingness, as the post-consumer-culture songs such as "Furniture Man" that Child and Smith mutually shunned.

Of course, this is not to suggest that the South, or rural areas generally, were not poor in the 1920s. Otherwise, the hunger of Boggs's "Country Blues," whose singing has been described by Marcus as sounding "as if his bones were coming through his skin" ("Dock Boggs" 1)-

Give me corn bread when I'm hungry, good people

Corn whisky when I'm dry

Pretty women a-standing around me

Sweet Heaven when I die

—or Uncle Dave Macon's achingly comical "I'll Keep My Skillet Good and Greasy" or "Country Ham and Red Gravy"-

Oh how them peoples yell

when they heard that dinner bell

oh how them onions smell

three miles away

—would not be so palpable. Otherwise, hundreds of thousands of rural Americans (like millions of immigrants) would not have left their homes in rural parts of the Carolinas, Virginia, or Tennessee for Atlanta, Baltimore, Chicago, St. Louis, and Detroit (Eller 157). Yet while wealth was certainly distributed unequally between urban and rural areas (just as it was distributed unequally between the elites of American cities and poor migrants), relative poverty did not keep people from consuming, and it did not keep the market out of poor places. Justice himself was poor enough for his voice nearly to crack with joy on the word "lard"-remember, the girl of his song brought him (corn) meal and lard, hardly the staple foods of the rich-but not so poor as to be unacquainted with furniture on the installment plan. Even Uncle Dave Macon's country ham came not from the pen but from the butcher. It is this fusion of persistent poverty and burgeoning consumerism that characterized the music of the recording boom, and that marked the transition of rural America 
from an isolated, backward region to one that was becoming integrated into a powerful national and international economy.

What is important to remember about this process, particularly in light of its position within a much longer trajectory of market integration that began well before the literature on the culture of consumption (or, for that matter, recent accounts of globalization) suggests, is that it happened not only because outsiders brought the market in but because insiders became outsiders to seek the market and then willingly brought it back. In the case of urbanization, as in the case of immigration, migration was not a single voyage but a series of returns, each of which entailed cultural, social, and economic interminglings that cannot simply be described as the dominant dominating or the subaltern submitting. ${ }^{20}$ Rather, in both cases the two-way circulation of people, goods, and money produced changes not only in the places that received migrants but in the places that lost them and that, in some populations, then gained them back. It was in this context of integration through circulation-the context of emigration and return migration, of financial, cultural, and intellectual remittances such as country records or, in two only slightly different contexts, of futurist cityscapes of New York or subscriptions to the Defender - that a transregional as well as transnational market modernity was made in the decades surrounding the turn of the twentieth century and in the decades that surrounded them. The fact that the discourses produced in the circulatory response to modernity were so different should not mask their similarities. While Emmett Miller's "Riley the Furniture Man" and Italian-American painter Joseph Stella's Brooklyn Bridge (1917-19, Yale University Art Gallery) appear to look nothing like each other, Miller and Stella-the transregional "Minstrel Man from Georgia" who made jazz and country while wearing the vestigial mask of blackface and the transatlantic modernist who made abstract New York cityscapes in the antiquated garb of the Mezzogiorno bourgeoisie-most certainly did. ${ }^{21}$

Looking at Miller's career again, then, the circulatory nature of rural cultural consumerization-and the agency of those who made it — can be seen very clearly. Although it may seem at first (as it would have to Smith) that the point at which Miller became part of the recording boom-read either as folk insurgence or emergent modernity - was the moment that he, like the Carter Family, was "discovered" by Peer in Asheville, North Carolina, this was not the case (Wolfe, Classic Country 2-5). ${ }^{22}$ Indeed, this meeting occurred in 1925, after Miller had already been doing blackface around the South for over five years and, more importantly, after he had already been to New York to record and perform. Like the Carters, then, whose initial search for the market led them only so far as Bristol, 
Tennessee, but who would venture to such media and market hot zones as New York and Mexican border radio in the course of their quest for success, Miller was clearly seeking the market.

More than that, this meeting and the meetings in New York that followed it did not constitute Miller's consumption by a fixed and hegemonic urban commercial culture but his creation of some of the most recognizable signs of one of the few discourses in which the poor South has played a dominant role in American popular and commercial culture-country music. For, although Miller remained personally obscure, his musical signatures - the midword falsetto of "Lovesick Blues," which helped make Williams famous, and the country swing of "Right or Wrong," which made Bob Wills a mintdid not (Malone, Country Music 235-36). And, although Miller is forgotten and Krupa and the Dorseys are famous, country is still big, big money and jazz is not. So, to suggest that rural Americans were merely passive victims of economic and cultural integration in the 1920 s is a mistake, for two reasons.

First, looking back, it is hard to argue that engagement in the market necessarily made things worse for the rural Southern poor. While one can argue that, by choosing the market as their hybrid language, the subaltern speakers of the South lost their voices-an argument that would certainly seem to be supported by some of today's country music, despite the lingering audibility of regional signatures - in other, extremely important respects they made gains. Despite the persistence of relative poverty in the rural South and despite the excesses of capitalism in the current age, it is significant that not even revivalists from New York are entrenched enough in authenticity these days to remember to sing about lard. ${ }^{23}$

Second, the case of the recording boom shows quite clearly that 1920s rural America-like so many "traditional" culture nexuses whose prehistories turn out to be as hybrid and as commercial as they are unitary and communitarian-was already commodified. This, then, helps to explain why so many of the old-time songs recorded in the pre-Depression era-including, most importantly, the "Furniture Man" genre-were about the consumer economy. Take, for example, the Carter Family's "Single Girl, Married Girl," which, like Justice's "Henry Lee," was somewhat surprisingly resurrected on Smith's Anthology of American Folk Music. ${ }^{24}$ In this 1927 recording, Sara Carter (1898-1979) of Maces Spring, Virginia, plays an autoharp from the Sears catalog and sings, explicitly linking happiness to consumption:

Single girl, single girl, she's going dressed fine Oh, she's going dressed fine

Married girl, married girl, she wears just any kind 


\begin{abstract}
Oh, she wears just any kind
Single girl, single girl, she goes to the store and buys

Married girl, married girl, rocks the cradle and cries, rocks the cradle and cries
\end{abstract}

And, like the more familiar urban girls of the same 1920s - the flappers and the blueswomen who exchanged marriage and motherhood for cigarettes, contraband whisky, and cocaine-Carter explicitly joins female consumption to female liberation. ${ }^{25}$

Justice's vision of consumer culture is much darker. In "Cocaine," the narrator is not the only person whose identity shifts: so, too, does that of the Furniture Man, who in Justice's version and those of many others is actually "the Devil without horns," who seems to have taken time off from tempting musicians at the crossroads to get them to buy furniture on credit. Thus, while Justice's narrator professes to the bitterest of ends to be really wild about his good cocaine, he cannot say the same about the market for things. He sings,

Furniture man came to my house once last Sunday morn

Asked me was my wife at home

Said she'd long been gone

Backed his wagon up to my door

Took everything I had

He carried it back to the furniture store

Honey, I did feel sad

What in the world has any man got, now

Messin' with the furniture man?

If you've got no dough, damn for sure

Certain will back you back

Take everything from an earthenware plate

From a skillet to a frying pan

If there ever was a devil, boy, without any horns

Must have been the furniture man

If in the early nineteenth century, as Lawrence Levine famously asserts, William Shakespeare was familiar enough that his works could be parodied in the crudest rural American performances, by the 1890s he had been joined by the Furniture Man and his false promises. $^{26}$ As the South made the transition from a produceroriented society to a consumer-oriented one, from poverty to wealth, and to an economy in which the involuntary chains of debt peonage were being traded for the willing shackles of consumer goods on credit, the Furniture Man was a powerful and dark symbol of change. 
At the same time, however, his appearance, as I have argued, was a sign that the South had already changed. By the 1890s, and even more so by the 1920s, the South was modern: although segregated, although underdeveloped, although relatively isolated, it, like "mongrel Manhattan," was hybrid and transgressive, was prosperous enough to consume and consume avidly, and was on the road to the market integration that would lay the groundwork for globalization. Thus, when we look to the South for the "old, weird America" and to the underdeveloped regions of the world for a world before globalization-the premodern, the preconsumerist, the culturally authentic-we should remember that things are not always what they seem. And, when we think that we are the only generation sophisticated enough to both enjoy and to critique consumerism, we should remember that the subaltern can deliberately and knowingly sacrifice meaning for pleasure.

\section{Technologies of Containment: Or, Modernism is an Anthology}

So, then, what happened to the things that Justice made? For all its modernity, "Cocaine" sank into oblivion, not to be re-released until the 1970s. Justice's Child ballad "Henry Lee," on the other hand, attained a privileged place in the annals of American folk-music history, as selection 1 of volume 1 of Smith's 1952 Anthology of American Folk Music. This six-volume set was arguably the most important single influence on the folk revival of the 1960s. As Robert Cantwell argues, the music on the Anthology provided the postwar generation with "a new world in which to live" (226); it "was a kind of curriculum in mystical ethnography, converting a commercial music fashioned in the twenties out of various cultural emplacements and historical displacements into the 'folk' music of the revival" (190). It has also had a major impact on the trajectory of rock and roll. As the liner notes to the edition released in 1997 by Smithsonian Folkways Recordings proudly advertise, several generations of musicians on the road to Damascus have been struck down by the Anthology, including Bob Dylan and Elvis Costello, and virtually every track on it, with the exception of some of the more obscure religious and Cajun numbers, have been covered by acts ranging from Nick Cave and the Bad Seeds to Huey Lewis and the News. Indeed, it could be argued that the Anthology is only growing in influence, as its reissue appears to have launched yet another folk revival, exemplified by the hugely successful sound track to O Brother, Where Art Thou? 
All of the songs contained in the Anthology, including "Henry Lee," were recorded for commercial concerns during the boom years before the Depression. But for Smith, who faced the recording boom from a post-Depression, postwar horizon that barely glimpsed the commercial viability of the $78 \mathrm{~s}$ that now lay in warehouses, secondhand stores, and attics, the raging consumer culture of the 1920s did not appear so bankrupt as what lay before him. ${ }^{27}$ Thus, unlike his fellow anthologizers Crawford Seeger and Lomax, who were wedded to field research, notational transcription, and other mechanisms of academic musicology (and who were rewarded for it by institutions like the Library of Congress), Smith believed that the sounds on the commercial recordings of the prewar period held the key to an authentic American culture that had disappeared into the conformity of the Cold War. ${ }^{28}$ And, while Crawford Seeger sought to use the written language of Western art music - which she in her vanguardist guise had already used to represent "experimental, dissonant, and transcendental" sound (Tick 144) - to convey the heterogeneous musical sounds of the American folk, Smith believed that audiences had to hear the sounds themselves, even if that meant a turn back to the recording industry.

If Smith's search for tradition employed a slightly different methodology than those employed by his fellow anthologists, however, they had more in common with him than not. For one thing, they shared the same driving ambition: to capture a disappearing American tradition and to evangelize on its behalf. And, despite their methodological differences, Smith, Crawford Seeger, and Lomax employed the same basic approach to this project: the development of technologies for the containment of authenticity. In Smith's case, this meant the new technology of the long-playing album, which could convert dozens of solitary songs into a visionary whole that did not itself resemble a commercial product but rather a collection of sacred texts, a point that is emphasized both by Smith's oracular cover illustrations and celebrated liner glosses. Smith's cover, for example, featured mystical looking drawings of the "Celestial Monochord," which symbolized not only the measurably disappearing past of the home-made instrument but "primitive" music as a whole (Marcus “Old, Weird America" 5-6). In Lomax's case this meant the evolving inscriptional technology of the field recorder. Zealously inverting Jean Ritchie's father's 80-mile walk to get a talking machine, Lomax and his own father famously lugged this device across America in the 1930s in search of the dying sounds of cowboys and sharecroppers; ${ }^{29}$ he then took it to Ireland, Spain, and Italy in the 1950s to record harmonizing longshoremen and picturesque rogues and thence in the post-Anthology era back into the South to disprove Washington Square's claim to be the only place left where folks 
were still playing the old-time music. ${ }^{30}$ What this technology inscribed, in Lomax's view, was not things but the immanent expression of a silenced folk. As he described it, "the incredible thing is, that when you would could play this material back to people, it changed everything for them. They realized that their stuff and they were just as good as anybody else. Then I found out that what I was really doing, and my father was really doing, was giving an avenue for those people to express their themselves and tell their side of the story" (Interview).

As her biographer, Judith Tick, argues, classically trained modernist composer Crawford Seeger was also worried about the ascendance of commercial popular culture, particularly the false "sweetness" of the nursery songs fed to American children (286). The purpose of her anthologies, like Smith's and Lomax's, then, was to give Americans anthological access to the true, honest, and harsh musical tradition that was being supplanted by commercial music. In Crawford Seeger's case, this meant not only using new inscriptional technologies such as the abstract language of the musical avant-garde and the variable-speed Ansley turntable to render the disappearing sounds and words that Lomax had found in the field; ${ }^{31}$ it also meant entextualizing the resulting notations into living anthologies that could themselves reverse the tide of reification. ${ }^{32}$ Crawford Seeger's anthologies thus took the form of books of sheet music, first made for Crawford Seeger's own young children Peggy, Michael, and Barbara (and eventually for her last child, Penny, born in 1943), then made for the Silver Spring Cooperative Nursery School in 1941, and then made as mass-circulation paperbacks for the folkways-inclined middle class in the form of the hugely successful American Folk Songs for Children (1948) (Tick 280-90). As manuals for instruction, Crawford Seeger's anthologies were meant not only to provide the coming generation with an alternative, "traditional" form of music to consume but also to retransform music from thing into practice. As her stepson Pete Seeger, whose career was singularly driven by this urge, put it in his recording of "Skip to My Lou": "You know there's a lot of good music in our country you never hear on the radio, don't hear it on the jukeboxes or on television. Just ordinary old-fashioned songs which one person teaches to another. Maybe old grandmothers teach it to the little grandchildren and the grandchildren grow old and they teach it to their grandchildren. Let me show you what I mean-maybe you all know this one-hey, sing it with me."33

Indeed, given that the "folk" songs Crawford Seeger transcribed were not, in many cases, ever widely performed until after she translated and published them and they became a canon in their own right, it is not too much of a stretch to describe her efforts as more than merely 
a nostalgic effort to preserve the disappearing past. Rather, she seems to have been engaged in a more ambitious and yet typically modernist plan, like that of Ezra Pound in his appropriation of Noh drama, to "split" and reorder time itself-to create, in the form of childrens' performances, a drama in which, as Peter Nicholls describes it, "the irruption of the past in the present mak[es] the point of greatest intensity that in which time flows back on itself and two moments are, as it were, superimposed or grafted together" (177) and the past is "completed only in the present" (178).

Whether Crawford Seeger deliberately adopted Pound's response to the "problematic of time" is unknown (167). What is more certain is that her commitment to the reanimation of the folk tradition had far-reaching effects, and not only in terms of her own work. That not only her stepson Pete but her son Mike and her daughter Peggy would make careers of this strategy-and become three of the most important figures in American folk music in the twentieth century-is perhaps the best proof of Crawford Seeger's success. In the hands of Pete Seeger, this model of cultural reanimation not only provided a powerful musical model but, as Cantwell argues, a "practical instrument" for political resistance: "[F]olksinging as ... a symbolic model of American community visibly and audibly purified of all the bureaucratic, authoritarian, corporate, and commercial elements in American life" (149). This is echoed in the career of Peggy Seeger, whose work included the sound track to Philip Donnellan's film The Irishmen (1966), ${ }^{34}$ a brutal chronicle of postwar life among the London Irish whose most moving scenes posed traditional musical practice as the tragic antidote to what modernity does both to people and to culture. ${ }^{35}$ That this work emerged not only from her mother's influence but from Peggy Seeger's deep personal and professional partnership with Britain's best-known folk revivalist, Ewan MacColl, suggests once again the circulating, hybrid and fluid nature of the movement—not just in the US but in a more global context. For, like an emigrant seeking return, her partnership with MacColl also produced a body of hybrid anthologies of authenticity such as Classic Scots Ballads (1959), in which the singer from Silver Spring and Chevy Chase, Maryland, struggles heroically to fit all the extra syllables necessary to make Child's "False Lover Won Back" and "The Trooper and the Maid" sound appropriately "Scottish."36

If as technologies for the containment and reanimation of authenticity the anthologies drew upon the same metadiscursive blueprint, their content also overlapped significantly. While the folk canons made by Lomax, Crawford Seeger, and Smith can hardly be described as identical, they shared a strategy of inclusion and distinction. In some respects, this was due to the fact that they knew each other 
and worked together: Crawford Seeger collaborated with Lomax not only on the work of transcription but on the resulting songbooks Our Singing Country (1941) and Folk Song U.S.A. (1947). More than that, however, all three figures shared abiding attitudes towards cultural and historical change that underpinned their participation in the anthological project even before they became tied by professional interests. Not only were they anxious about the disappearance of American folk music and its replacement by consumer culture, but I would argue that they were connected by a deeper worry shared by other observers who have sought to formulate a meaningful response to modernity since at least the middle of the nineteenth century.

One worry the musicologists shared was that modern time had become speeding and unstoppable. More specifically, Smith, Lomax, and Crawford Seeger's project is defined by the classic modernist fear that the rapid pace of social and economic change was rapidly robbing modern people of the capacity to produce their own culture. One response to this, from the nineteenth century to the present day, has been the repeated call for the restoration of practice. This can be seen in Henry David Thoreau's resolution, in the midst of shrieking, machine-powered modernity, thriftily to build his own house; in Thomas Eakins's repeated turn, in the hyper-industrializing Reconstruction years, to the subject of spinning in paintings such as $\mathrm{Sev}$ enty Years Ago (1877, Princeton University Art Museum); and, in the present day, in Dylan Evans's insistence that we must all learn to write computer code lest we be overwhelmed by the most recent global technological revolution. As Evans apocalyptically puts it, "If you want to remain inside the dream world of The Matrix, that's your choice" (26). Another response, which as Crawford Seeger's work suggests was intimately intertwined with the first, was to collect and rehabilitate seemingly disappearing, seemingly premodern communities such as the people of Appalachia, who symbolized the fragile persistence of authentic practice. Thus, it is no accident that Smith's anthological activities were not restricted to folk music; they extended to other emblems of disappearing time: he also anthologized Native American culture and even regional American accents, whose identification he turned into his signature party game (Luc Santé, qtd. in Smith, Booklet 30-31). In this he drew upon a long ethnographical tradition in American social science, art, and literature, from Henry Rowe Schoolcraft and George Catlin through Lewis Henry Morgan to Franz Boas, to preserve the practices of "disappearing" American cultures through visual or textual anthologies. ${ }^{37}$

It is also no accident that Lomax went not only to remnant American regions like Appalachia and the Mississippi Delta but to Ireland, which for so many observers had represented timelessness, 
or at least circularity, in the midst of a linear and apocalyptic Europe ${ }^{38}$ There, like his fellow modern, the painter Robert Henri (who unlike so many not-quite modernist commentators of the eighteenth and nineteenth centuries found in the people of Achill Island not an excuse to deride and belittle "backward" Ireland but the means in ethnological portraiture to stop the ticking clock of rapacious modernity), Lomax found the music he was looking for (even if it was sung by his fellow anthologist Ennis). ${ }^{39}$

I do not mean to suggest that the anthologies do not contain songs about the modern world. Indeed, they frequently refer to the history of industrialization and capitalism and to the struggles against their domination. More telling, however, is that they almost never refer-at least not directly - to the much more immediate but much more threatening world of twentieth-century consumer culture. Thus, while the Anthology contained only songs that were made for the market-including two tracks from Uncle Dave Macon, who was not only one of the great travelling medicine show performers of the early twentieth century but one of the stars of the early Grand Ole Opry ${ }^{40}$ - it, like Crawford Seeger and Lomax's work, deliberately shunned the Furniture Man, the industry-making songs of Stephen Foster, and even Carson's "Little Old Cabin in the Lane," which (as a sheet-music standard) might have reminded people of old-time music's roots in consumer culture. Indeed, Crawford Seeger purposefully excluded Foster's "Old Folks at Home" and "My Old Kentucky Home," which had been the only American songs in the most popular folk songbook to precede American Folk Songs for Children (Tick 283). ${ }^{41}$ This meaningful suppression of the sentimental Southern repertory placed Crawford Seeger in contrast with certain other urban modernists, who occasionally recognized its subtextual place in modernist culture. As Charlie Chaplin prepares for his climactic dadaist cabaret performance in Modern Times (1936), for example, the singing waiters perform a lament for the plantation which, due to the contrasting action of the scene, only rises to the level of full audibility upon repeated viewing. If not penned by Foster himself, this number certainly refers to the work of Foster, Hays, and their contemporaries. Similarly, among the numerous commercial standards Charlie Parker recorded, was a 1953 rendition of "Old Folks" - "and that old corn cob pipe, it's so mellow it's right"which contains the telling and memorable lyric, "Did he fight for the Blue or the Grey?"

Rather than sheet-music standards or contemporary songs about consumer culture, the anthologies instead mostly include songs such as "Peg and Awl," which Smith mistakenly read as a protest against mechanization; vast numbers of songs about the (by then charmingly old-fashioned) railroad, such as Williamson \& 
Curry's "John Henry," the Carter Family's "Engine 143," and Furry Lewis's "Kassie Jones" (on the Anthology), Lomax's field recordings of "John Henry" on Sounds of the South, and Crawford Seeger's arrangements of the same for Folk Song U.S.A.; and songs about poverty such as The Bently Boys' "Penny's Farm," which re-emerged, in one post-Anthology incarnation, as Dylan's "Maggie's Farm." 42 As in the case of the railroad songs, however, which surely looked backward rather than forward, this tale of debt and destruction refers not to willing, modern consumer debt but to actual market slaverynot to the small luxuries on credit that would, figured as radios or Nikes, seem so corrosive to critics of consumerism then and now but to wholly involuntary debt peonage at the hands of an entrenched, vestigial planter class.

"Penny's Farm" is driven, moreover, by protest. Indeed, in the few cases where songs about more modern forms of capitalist integration crept into the anthologies, the element of protest is foremost. For example, the only version I have found of "Furniture Man" in the folk anthology is in Lomax, Woodie Guthrie, and Pete Seeger's Hard Hitting Songs for Hard-Hit People (1967), where it takes its place alongside the protest classics "Silicosis is Killing Me" and "Roberts' Farm" (a version of "Penny's Farm"). In this context, however, "Furniture Man" has been transformed almost beyond recognition. In place of Justice, Miller, and McClintock's addicted and worried yet still witty and expansive ruminations on modernity, the folk version offers the following humorless advice:

I say, folks, don't buy nothin, Lord on the installment plan

And you will not be worried, Lord

by no collector man .... Oh, how it would be if I could just explain

But Depression has me, it's 'bout

to drive me insane. (42-43)

Similarly, one suspects that Smith and Lomax included songs about the Titanic not because they provided a fascinating glimpse into the already globalized world of the early sensationalist media, but because they told listeners that in the age of radio prophecy was still safer than technology; ${ }^{43}$ and that Smith chose "Single Girl" not because Sara Carter bought her autoharp from the Sears catalogue, but because she told Southern women that marriage was a fraud.

The folk anthologists' response to modernity was not entirely nostalgic. Their goal, after all, was to use the past to make a future that was better than the past-to use music to combat injustice and degradation and create a world of greater racial, gender, and economic 
equality - to find, as Cantwell put it in Lomax's case, "the way out of [a] suburban False Paradise into the True Paradise of a realized democracy" (79). ${ }^{44}$ But they had trouble recognizing what about the present, aside from the thrifty protest spirit of the 1930s (and later the 1960s), would be useful in making such a future. Although surrounded by music that dwelt on the potentials, as well as the dangers, of consumer culture, the folk anthology would not recognize that for rural musicians themselves the hybrid consumer modernity of the 1920s was not a distraction from this goal but a constituent element of its attainment.

\section{Notes}

This research was generously supported by the Faculty of Arts, University College Cork-National University of Ireland, Cork.

1. On Boggs, see O'Connell; M. Seeger; and Marcus, "Dock Boggs." The best single source on the recording boom is still Malone, Country Music U. S. A., esp. 33-78; on the folk revival, it is Cantwell. See 40-44 for Cantwell's comments on Mike Seeger. For an interesting interpretation of early country music's deliberate appeals to authenticity, see Peterson.

2. See, e.g., A. Douglas and Erenberg.

3. On Evans and "documentary" photography see, e.g., Orvell 283-85, 231-39.

4. I am thinking, for example, of Nicholas Dawidoff's patronizingly picturesque In the Country of Country: People and Places in American Music, which presents country music through the juxtaposition of images like Evans's photograph of a child's grave with quotes from Steinbeck and narratives such as this one: "Stories were unfolding even as the music played. Some of them were about snakes ... and others concerned feuds. One well-known local hostility began at a square dance when a young man drew up some water from a well and drank straight out of the bucket instead of using a dipper.... [T] hen nearly everyone joined as the band struck up 'Will the Circle Be Unbroken?,' a Carter Family song as familiar to Southern country people of a certain generation as 'When Irish Eyes Are Smiling' used to be in Hell's Kitchen" (vi-6). For an elegantly argued alternative to this method of representation, see Whisnant.

5. This is not to say this backlash did not take place. See, e.g., Marsden; Blee; Baiamonte; and Ownby. Klein's major work is No Space, No Choice, No Jobs, No Logo.

6. The literature on the minstrel show is vast. See, e.g., Cockrell; Lott; Mahar; Rogin; Toll; and Linn. On vaudeville, see Snyder. For a more general view on the interracial cast of Southern music, see Joyner ch. 10.

7. Both songs can be found on Hutchison. 
8. Recorded variants of this song include Georgia Crackers; Chitwood and Landress; McClintock; Spivey and Johnson; and White.

9. On the Great Migration, see Grossman; Phillips; Trotter; L. S. Williams; and Zunz. Much less is known about white Southern migration during this period, either within the region or beyond. Of help are Eller 125, 157 and two studies that concentrate on the better-understood later periods of migration: Berry and Gregory.

10. On Miller, see Wolfe, Classic Country 182-84 and Tosches, Where and Country $98-02,105-08$.

11. Recordings of Miller's incarnation as a bridge between blackface and jazz is captured on his Minstrel Man from Georgia, released as part of the Columbia Roots and Blues series. Although these tracks also contain examples of Miller's signaturessignatures that would be more important to country figures like Bob Wills and Jimmie Rodgers-the album unfortunately lacks any examples of Miller's "country" recordings, such as "Riley," which have not been anthologized in this way.

12. See also Sollors, Interracialism.

13. See, e.g., Lee's The Hispanic Project.

14. See Benson; Fox and Lears; L. Glickman; Horowitz; Leach; and Marchand. On credit in particular, see Calder and Olney.

15. See in particular A. Douglas; Erenberg; and Stansell. I do not mean to suggest that the literature on the city is not important or persuasive. But there are too few studies on rural areas to match this literature or to provide a rural counterpart to works that trace the earlier origins of urban, modern consumer culture such as Kasson and Peiss.

16. I am referring, of course, to the "virtual" web of cinema and radio, as well, which saw an increase, in the case of radio from sales of $\$ 60,000,000$ in 1922 to a staggering $\$ 842,548,000$ in 1929 (Malone, Country 34).

17. There is not enough space here to do justice to the country blues boom that paralleled the recording of country music in the 1920s. What is worth noting here, though, is the essential similarity between the events surrounding McClintock's Columbia session-a session in which he recorded two gospel tracks as well as "Furniture Man" and another minstrel-influenced number-and the circumstances by which country was recorded. Bastin provides an outstanding analysis of the correlation between emerging consumer culture, market integration, and the emergence of the blues. McClintock's journey is noted on 188-89. See also Ayers 373-93.

\section{See Wolfe, Classic Country 64-69 and Peterson.}

19. Collections that show the range and hybridity of the sheet-music market in nineteenth- and early-twentieth-century America include Tawa, American Solo Songs 1866 through 1910 and American Solo Songs through 1865; S. Glickman; and Jasen, "Alexander's Ragtime Band" and Thirty-Five. The latter includes a number of songs recorded by Miller. For contemporary and historical views on mail order, see Keller and Elkington. This technology, I might add, has served a particular 
purpose in building an audience not only for easily recognizable "modern" consumer goods (or, at another globalizing, modern extreme, "mail-order brides") but also for markers of authenticity such as Navajo blankets. See, e.g., L. L. Williams.

20. The best single source on this regarding immigration is Wyman.

21. On Stella, see, e.g., Corn; on the Defender, see Grossman and Tuttle.

22. Smith puts it this way: "The modern era of folk music recording began shortly after World War I when Ralph Peer, of Okeh Records, went to Atlanta with portable equipment and a record dealer there offered to buy 1000 copies if Peer would record the singing of circus barker 'Fiddling' John Carson."

23. Although Mike Seeger's classically revivalist New Lost City Ramblers recorded "My Name is John Johanna" ("I got so thin on fatback, I could hide behind a straw"), virtually none of their other songs convey the basic hunger of the rural past. Rather, the songs tend towards other categories: ballads such as "Barbara Allen," cartographic markers such as "Cumberland Gap" and "Shady Grove," and bad-man songs such as "Jesse James." Thus, while their recordings such as "Worried Man Blues" and "Oh Death" tell us that, as one album put it, "There Ain't No Way Out," it is difficult at times to determine exactly what people were trying to escape.

24. "Single Girl, Married Girl" also resurfaced on a New Lost City Ramblers recording as well (Smith, Booklet 60).

25. On blueswomen and feminism, see, e.g., Carby and Davis.

26. For Levine's argument, see "William Shakespeare" and Highbrow/Lowbrow.

27. On Smith's Anthology as a response to Cold War conformity, see Marcus, "Old, Weird America" 5-25 and Cantwell.

28. For an excellent account of Crawford Seeger's life and career, see Tick. On her transcription work with Lomax, see 247-67.

29. On the adventures of the Lomaxes, see Filene, "Our Singing Country" and Romancing the Folk.

30. Lomax's comments are worth quoting here:

I had been recording in the field for twenty-five years-beginning with the Edison cylinder machine and every few years moving on to a better devicebefore stereo came along. After years of work in Europe during the '50s I returned to America to find the folk song revival, that I had earlier helped to launch, in full swing. Where Burl and Pete and Woody and Leadbelly and a few others had held sway, now there were hundreds of singers and scores of groups. Some of the young folkniks, who dominated the New York scene, asserted that there was more folk music in Washington Square on Sunday afternoon than there was in all rural America. Apparently, it made them feel like heroes to believe that they were keeping a dying tradition alive. The idea that these nice young people, who were only just beginning to learn how to play and sing in good style, might replace the glories of the real thing, frankly, horrified me. I resolved to prove them wrong. Thus in the summer of 1959, supported by Nesuhi and Ahmet Ertegun of Atlantic Records, 
I returned to my native South, where I had worked before, to record the singers of mountain, bayou, prison and cotton patch with state-of-the-art equipment. ("Introduction")

31. Tick writes, "The turntable had no fixed rpms, but was variable from a little below $33 \mathrm{rpm}$ to $80 \mathrm{rpm}$. When stuck, Ruth could slow down the speed, and even though the pitch would change, the relationships between pitches remained constant. She called the Ansley turntable a 'godsend,' her 'new toy"' (265).

32. Such anthologies could as objects convey a modernist kind of immanence: "As Pete [Seeger] said, 'Father and Ruth were trying to get these songs "done right." 'Done right' meant 'authentically' or as close as possible to original tradition in musical style and in spirit. Crawford's credo, stated simply, was to give people a taste for 'the thing itself'" (Tick 285).

33. On Seeger's career as an agent of audience participation, see Filene, Romancing the Folk.

34. Sheet music for the sound track to The Irishmen can be found in MacColl and Seeger, I'm a Freeborn Man.

35. Lomax also worked with MacColl, as well as with his Irish counterpart Seamus Ennis, on projects such as The Skiffle Album (whose cover boasts a photograph of Lomax, Pete Seeger and MacColl merrily turning things into practice), Lomax and Ennis's recording Ireland: Irish Folk Songs from the Western Counties of Eire for the Columbia World Library, and numerous radio broadcasts in the 1950s. Lomax also co-edited, with Peter Kennedy, the 10-volume Folk Songs of the British Isles.

36. Seeger herself, whose definitions of authenticity became more precise over the course of time, described this effort rather less charitably as an "inept attempt at a Scottish accent."

37. For a provocative discussion of Boas in this context, see Briggs and Bauman.

38. For attitudes on time expressed in and about Ireland, see K. Miller.

39. See, e.g., Ennis, “As I Roved Out” on Lomax, Alan Lomax.

40. On Uncle Dave Macon, see Wolfe, "Uncle Dave Macon."

41. This volume was Archibald T. Darison and Thomas Whitney Surette, 140 Folk-tunes, with Piano Accompaniment, Boston: Boston Music Co. [C. 1921].

42. A useful anthology of railroad songs is N. Cohen.

43. As the version Lomax had Bessie Jones recreate for a film shoot in 1960 about colonial Williamsburg-itself a fascinating manifestation of the anthological urge - put it, "God moved on the waters, even after fourteen days / God moved on the waters, everybody had to run and pray." For a discussion of the Titanic in the history of the media, see S. Douglas 216-39.

44. See also R. Cohen. 


\section{Works Cited}

Ayers, Edward L. The Promise of the New South: Life after Reconstruction. New York: Oxford UP, 1992.

Baiamonte, John V., Jr. Spirit of Vengeance: Nativism and Louisiana Justice, 1921-1924. Baton Rouge: Louisiana State UP, 1986.

Bastin, Bruce. Red River Blues: The Blues Tradition in the Southeast. Urbana: U of Illinois P, 1986.

Benson, Susan Porter. Counter Cultures: Saleswomen, Managers, and Customers in American Department Stores, 1890 1940. Urbana: U of Illinois P, 1986.

Berry, Chad. Southern Migrants, Northern Exiles. Urbana: U of Illinois P, 2000.

Blee, Kathleen M. Women of the Klan: Racism and Gender in the 1920s. Berkeley: U of California P, 1991.

Boggs, Dock. Booklet. Dock Boggs: His Folkways Years 1963-1968. Smithsonian Folkways, 1998.

Smith vol. 3 .

Briggs, Charles, and Richard Bauman. "The Foundation of All Future Researchers': Franz Boas, George Hunt, Native American Texts, and the Construction of Modernity." American Quarterly 51 (1999): 479-528.

Calder, Lendol. Financing the American Dream: A Cultural History of Consumer Credit. Princeton: Princeton UP, 1999.

Cantwell, Robert. When We Were Good: The Folk Revival. Cambridge: Harvard UP, 1996.

Carby, Hazel V. “'It Jus Be's Dat Way Sometime': The Sexual Politics of Women's Blues." Radical America 20 (1986): 9-22.
Carter Family. "Single Girl, Married Girl.” Rec. 1927. Smith vol. 3.

Chitwood, Bill, and Bud Landress. "Furniture Man.” Brunswick, 1925.

Cockrell, Dale. Demons of Disorder: Early Blackface Minstrels and Their World. 1997. Cambridge: Cambridge UP, 1997.

Cohen, Norm. Long Steel Rail: The Railway in American Folksong. Urbana: U of Illinois P, 1981.

Cohen, Ronald D. Rainbow Quest: The Folk Music Revival and American Society, 1940-1970. Amherst: U of Massachusetts P, 2002.

Corn, Wanda M. The Great American Thing: Modern Art and National Identity, 1915-1935. Berkeley: U of California P, 1999.

Davis, Angela. Blues Legacies and Black Feminism: Gertrude 'Ma' Rainey, Bessie Smith, and Billie Holliday. New York: Pantheon Books, 1998.

Dawidoff, Nicholas. In the Country of Country: People and Places in American Music. New York: Pantheon, 1997.

Douglas, Ann. Terrible Honesty: Mongrel Manhattan in the 1920s. London: Picador, 1996.

Douglas, Susan J. Inventing American Broadcasting. Baltimore: Johns Hopkins UP, 1987.

Eakins, Thomas. Seventy Years Ago. 1877. Watercolor on paper. Princeton University Art Museum, Princeton, NJ.

Eller, Ronald D. Miners, Millhands and Mountaineers: Industrialization of the Appalachian South, 1880-1930. Knoxville: U of Tennessee P, 1982. 
Erenberg, Lewis A. Steppin' Out: New York Nightlife and the Transformation of American Culture, 1890-1930. Westport: Greenwood, 1981.

Evans, Dylan. "Smash the Windows." Guardian 6 Nov. 2003: 26.

Filene, Benjamin. “'Our Singing Country': John and Alan Lomax, Leadbelly, and the Construction of an American Past." American Quarterly 43 (1991): 602-24.

Romancing the Folk: Public Memory and American Roots Music. Chapel Hill: U of North Carolina P, 2000.

Fox, Richard Wightman, and T. J. Jackson Lears, eds. The Culture of Consumption: Critical Essays in American History, 1880-1980. New York: Pantheon Books, 1983.

Georgia Crackers. "Riley the Furniture Man.” Rec. 1927. Georgia Stringbands, Vol. 1. Document, 1998.

- Times Ain't Like They Used to $B e$, Vol. 2. n.p., n.d.

Glickman, Lawrence B., ed. Consumer Society in American History: A Reader. Ithaca: Cornell UP, 1999.

Glickman, Sylvia. American Keyboard Music 1866 through 1910. Boston: G. K. Hall, 1990.

Gregory, James N. American Exodus: The Dust Bowl Migration and Okie Culture in California. New York: Oxford UP, 1989.

Grossman, James R. Land of Hope: Chicago, Black Southerners, and the Great Migration. Chicago: U of Chicago P, 1989.

Horowitz, Daniel. The Morality of Spending: Attitudes toward the Consumer Society in America, 1875-1940. Baltimore: Johns Hopkins UP, 1985.
Hutchison, Frank. Complete Recorded Works, Vol. 1 (1926-1929). Newton Stewart, 1997.

Jasen, David A., ed. "Alexander's Ragtime Band" and Other Favorite Song Hits, 1901-1911. New York: Dover Publications, 1987.

- Thirty-Five Song Hits by Great Black Songwriters: Bert Williams, Eubie Blake, Ernest Hogan and Others. Mineola, NY: Dover, 1998.

Jones, Bessie. "The Titanic." Lomax, Alan Lomax.

Joyner, Charles. Shared Traditions: Southern History and Folk Lore. Urbana: U of Illinois P, 1999.

Justice, Dick. "Cocaine." Rec. 20 May 1929. Old-Time Music of West Virginia: Ballads, Blues, and Breakdowns, Vol. 2. County, 1999.

Kasson, John. Amusing the Million: Coney Island at the Turn of the Century. New York: Hill \& Wang, 1978.

Keller, Alexandra. "Disseminations of Modernity: Representation and Consumer Desire in Early Mail-Order Catalogs." Cinema and the Invention of Modern Life. Ed. Leo Charney and Vanessa R. Schwartz. Berkeley: U of California P, 1995. 156-182.

Klein, Naomi. No Space, No Choice, No Jobs, No Logo. London: Flamingo, 2000.

Leach, William. Land of Desire: Merchants, Power, and the Rise of a New American Culture. New York: Pantheon Books, 1993.

Lee, Nikki. The Hispanic Project. 1998.

Levine, Lawrence. Highbrow/Lowbrow: The Emergence of Cultural Hierarchy in America. Cambridge: Harvard UP, 1988. 
"William Shakespeare and the American People: A Study in Cultural Transformation." Rethinking Popular Culture. Ed. Chandra Mukerji and Michael Schudson. Berkeley: U of California P, 1991. 157-97.

Linn, Karen. That Half-Barbaric Twang: The Banjo in American Popular Culture. Urbana: U of Illinois P, 1991.

Lomax, Alan. The Alan Lomax Collection Sampler. Rounder, 1997.

Interview with Charles Kuralt. Lomax, Alan Lomax.

-. "Introduction." Booklet. Sounds of the South: A Musical Journey from the Georgia Sea Islands to the Mississippi Delta. Atlantic, 1993.

[Lomax, Alan, Ewan MacColl, et al.]. The Skiffle Album: Featuring Skiffle and Folk Songs... Words and Music with Guitar Symbols and Fingering. London: B. Feldman, 1957.

Lomax, Alan, and Peter Kennedy, eds. World Library of Folk and Primitive Music, Vol. 2: Ireland. Rounder, CD, 1998.

Lomax, Alan, and Seamus Ennis. Ireland: Irish Folk Songs from the Western Counties of Eire. Columbia, C. 1951.

Lomax, Alan, Woodie Guthrie, and Pete Seeger. Hard Hitting Songs for Hard-Hit People. New York: Oak, [1967].

Lomax, John A., and Alan Lomax, eds. Our Singing Country. New York: Macmillan, 1941.

Duell, 1947.

Lott, Eric. Love and Theft: Blackface Minstrelsy and the American Working Class. New York: Oxford UP, 1993.
MacColl, Ewan and Peggy Seeger. Classic Scots Ballads. Tradition, 1997.

I'm a Freeborn Man and Other Original Radio Ballads and Songs of Gypsies, Prizefighters, Teen-Agersand Contemporary Songs of Struggle and Conscience. New York: Oak, [1968].

Macon, [Uncle] Dave. "Country Ham and Red Gravy." Traveling Down the Road. County, 1995.

"I'll Keep My Skillet Good and Greasy." Traveling Down the Road. County, 1995.

Mahar, William J. Behind the Burnt Cork Mask: Early Blackface Minstrelsy and Antebellum American Popular Culture. Urbana: U of Illinois P, 1999.

Malone, Bill C. Country Music U. S. A.: A Fifty Year History. Austin: U of Texas P, 1968.

- Singing Cowboys and Musical Mountaineers: Southern Culture and the Roots of Country Music. Athens: U of Georgia P, 1994.

Marchand, Roland. Advertising the American Dream: Making Way for Modernity, 1920-1940. Berkeley: U of California P, 1985.

Marcus, Greil. "Dock Boggs in Thomas Jefferson's Virginia." Representations 58 (1997): 1-23.

_. "Old, Weird America." A Booklet of Essays, Appreciations, and Annotations Pertaining to the Anthology of American Folk Music. Ed. Harry Smith. Washington: Smithsonian Folkways, 1997. 5-25.

Marsden, George M. Fundamentalism and American Culture: The Shaping of Twentieth Century Evangelicalism, 1870-1925. New York: Oxford UP, 1980. 
McClintock, Lil. "Furniture Man." Rec. 1930. Before the Blues, Vol. 3: The Early American Black Music Scene Classic Recordings from the 1920s and 1930s. Yazoo, 2000.

—. "Furniture Man." Rec. 1930. Georgia Blues and Gospel 1927-1931. Document, n.d.

Miller, Emmett. The Minstrel Man from Georgia. Columbia Records, 1996.

."Riley the Furniture Man." Rec. 1930. Georgia Stringbands, Vol. 1. Document, 2002.

."Riley the Furniture Man." Rec. 1930. Times Ain't Like They Used to Be, Vol. 2. Yazoo, 1997.

Miller, Kerby. Emigrants and Exiles: Ireland and the Irish Exodus to North America. New York: Oxford UP, 1985.

New Lost City Ramblers. "My Name Is John Johanna." Old Time Music. Vanguard, CD, 1994.

- There Ain't No Way Out. Smithsonian Folkways, 1997.

Nicholls, Peter. Modernisms: A Literary Guide. Basingstoke: Macmillan, 1995.

O'Connell, Barry. "Down a Lonesome Road: Dock Boggs' Life in Music." Dock Boggs, Dock Boggs 3-26.

Olney, Martha L. Buy Now, Pay Later: Advertising, Credit, and Consumer Durables in the 1920s. Chapel Hill: U of North Carolina P, 1991.

Orvell, Miles. The Real Thing: Imitation and Authenticity in American Culture, 1880-1940. Chapel Hill: U of North Carolina P, 1989.

Ownby, Ted. Subduing Satan: Religion, Recreation, and Manhood in the Rural South, 1865-1920. Chapel Hill: U of North Carolina P, 1990.
Parker, Charlie, Charles Mingus, and Max Roach, et al. "Old Folks." Rec. 1953. By Willard Robinson and Didette Lee Hill. Charlie Parker Plays Standards. Verve/PolyGram, 1994.

Peiss, Kathy. Cheap Amusements: Working Women and Leisure in Turn-ofthe-Century New York. Philadelphia: Temple UP, 1986.

Peterson, Richard. Creating Country Music: Fabricating Authenticity. Chicago: U of Chicago P, 1997.

Phillips, Kimberley L. Alabama North: African-American Migrants, Community, and Working-Class Activism in Cleveland, 1915-45. Urbana: U of Illinois P, 1999.

Rogin, Michael. Blackface, White Noise: Jewish Immigrants in the Hollywood Melting Pot. Berkeley: U of California P, 1993.

Seeger, Mike. "Some Personal Notes." Dock Boggs, Dock Boggs 3-26.

Seeger, Pete. "Skip to My Lou." Rec. 1959. Smithsonian Folkways Children's Music Collection. Smithsonian Folkways, 1998.

Smith, Harry, comp. Anthology of American Folk Music. 3 vols. Smithsonian Folkways, 1997.

Booklet. Smith.

. Foreword. Smith, Booklet.

Snyder, Robert W. The Voice of the City: Vaudeville and Popular Culture in New York. New York: Oxford UP, 1989.

Sollors, Werner, ed. Interracialism: Black-White Intermarriage in American History, Literature, and Law. Oxford: Oxford UP, 2000. 
Neither Black nor White yet Both: Thematic Explorations of Interracial Literature. New York: Oxford UP, 1997.

Spivey, Victoria, and Lonnie Johnson. "Furniture Man Blues, Parts I and II." Victoria Spivey: Complete Recorded Works, Vol. 2 (1927-1929). Document, 2000.

Stansell, Christine. American Moderns: Bohemian New York and the Creation of a New Century. New York: Metropolitan, 2000.

Stella, Joseph. Brooklyn Bridge. 19171919. Oil on canvas. Yale University Art Gallery, New Haven, CT.

Tawa, Nicholas, ed. American Solo Songs 1866 Through 1910. Boston: G. K. Hall, 1990.

American Solo Songs through 1865. Boston: G. K. Hall, 1989.

Tick, Judith. Ruth Crawford Seeger: A Composer's Search for American Music. New York: Oxford UP, 1997.

Toll, Robert C. Blacking Up: The Minstrel Show in Nineteenth Century America. New York: Oxford UP, 1974.

Tosches, Nick. Country: The Biggest Music in America. New York: Stein, 1977.

Where Dead Voices Gather. Boston: Little, Brown, and Co., 2001.

Trotter, Joe William, Jr., ed. The Great Migration in Historical Perspective: New Dimensions of Race, Class, and Gender. Bloomington: Indiana UP, 1991.

Tuttle, William M., Jr. Race Riot: Chicago in the Red Summer of 1919. Urbana: U of Illinois P, 1970.
Whisant, David. All That Is Native and Fine: The Politics of Culture in an American Region. Chapel Hill: U of North Carolina P, 1983.

White, Georgia. "Furniture Man." Complete Recorded Works, Vol. 4 (1939-1941). Document, 1996.

Williams, Lester L. C. N. Cotton and His Navajo Blankets: A Biography.... Albuquerque: Avanyu Publishing, 1989.

Williams, Lillian Serece. Strangers in the Land of Paradise: The Creation of an African American Community, Buffalo, New York, 1900-1940. Bloomington: Indiana UP, 1999.

Williams, Rosalind. Dream Worlds. Berkeley: U of California P, 1982.

Wolfe, Charles K. Classic Country: Legends of Country Music. New York: Routledge, 2001.

_. "Uncle Dave Macon." Stars of Country Music: Uncle Dave Macon to Johnny Rodriguez. Ed. Bill Malone and Judith McCullough. Urbana: U of Illinois P, 1975. 40-63.

Wood, Robert Elkington. Mail Order Retailing Pioneered in Chicago. New York: Newcomen Society of England, American Branch, 1948.

Wyman, Mark. Round-Trip to America: The Immigrants Return to Europe, 1880-1930. Ithaca: Cornell UP, 1993.

Zunz, Olivier. The Changing Face of Inequality: Urbanization, Industrial Development, and Immigrants in Detroit, 1880-1920. Chicago: U of Chicago P, 1982. 